\title{
Performance Based Teaching and Evaluation Process: An Effective Strategy for Controlling Examination Malpractice in Sciences, Vocational and Technical Education in Nigeria
}

\author{
Famiwole, R.0. \\ Faculty of Education, Ekiti State University, Ado-Ekiti, Nigeria \\ remifamiwole@gmail.com
}

Bandele S.O.

Faculty of Education, Ekiti State University, Ado-Ekiti, Nigeria samuelbandele@gmail.com

Ajayi-Vincent O.B.

Faculty of Education, Ekiti State University, Ado-Ekiti, Nigeria ajayivincent2006@yahoo.com

Doi:10.5901/mjss.2014.v5n2p317

\begin{abstract}
This paper identifies the mode of assessing learning outcomes in sciences, vocational and technical education in order to prevent examination malpractice. It also discuss the virtues of performance based teaching, checklisting and rating scales as effective strategies for controlling examination malpractice among students in schools and colleges in Nigeria. It was recommended that performance based evaluation process, through the use rating scale, checklisting and monitored continuous assessment should be adopted for assessing students learning outcome in sciences, vocational and technical education subject areas in order to prevent and control examination malpractice and its vices in schools and colleges in Nigeria.
\end{abstract}

Keywords: Checklisting, Rating scale, Performance based tests, Examination Malpractice Vocational and Technical Education, Learning outcomes.

\section{Introduction}

Evaluation of learning and teaching outcomes in Science, Vocational and Technical Education (SVTE), requires pragmatic approach devoid of examination vices and malpractice. Amadi (2011) defined examination malpractice as attempts by examinees, their agents or collaborators to influence the outcome of examination unfairly. According to him, such agents could be other students, teachers, invigilators and adults or even parents and guardians. Similarly, Oluyeba and Daramola (1992) viewed examination malpractices as any irregular bahaviour exhibited by candidates or anybody charged with the conduct of examination in or outside examination halls before, during or after such an examination,

In 1992, the Lagos State .Ministry' of Education, Youth and Sports defined examination malpractice as an act of using deceitful means in obtaining examination success, either during internal or external examinations. There are so many definitions of examination malpractice. In all the definitions, the end product is to make the examinee "Successful or Pass" at a!! costs even if the examinee cannot defend the result or grade awarded to them there after. In which case, the main goal of getting involved in examination malpractice is to secure certificate rather than acquired useful knowledge, skill or attitude with which to cope with the demands of modern life and needs of the labour market as stipulated in the National Policy on Education. (NPE, 2004)

Olaitan (2010), observed that in an era of high demand for accountability, skill development and education for self reliance, teaching and learning should be structured to meet the needs of the labor market, and the nation. This according to Olaitan can be achieved by preventing examination malpractice so as to maintain standard and measure actual performance and competency on the job. In 2011, Seweje remarked that teaching and learning process should be 
continually evaluated to determine whether they contribute to the behavioural changes desired in the students. This is expected to be achieved through a constant and systemic search for examination malpractice free evaluation process. This paper therefore identifies the virtues of performance based teaching and evaluation process that can be used to control examination malpractice among students in schools and colleges in the country.

\section{Causes and Incidence of Examination Malpractice in Schools and Colleges}

There is hardly any issue in the Nigerian education system that has generated more serious discussion and raised mare concern today than the issue of funding of education and examination malpractice in public and private schools and colleges. According to Oluyeba (1998), apart from its frequent and increasing occurrences, examination malpractice have eaten deeply into the fabrics of the nation's educational system to the extent that it has become a pollutant, having a serious debilitating effects on the assessment of the curriculum objective, actual teaching and learning outcomes. In Nigerian schools and colleges today, the behaviour of the examinees toward examinations and their eventual performance could be a rational base on which to assess the standard of education in the country. To this end the attitude of an average examinee has made most people and the employers of labour to doubt the validity and authenticity of certificates issued at ail levels of educational system in the country.

It is believed that this trend should not continue but be stepped down if the nation would not become worst for it. To combat examination malpractices, it is necessary to identify the major causes. The major causes of examination malpractices identified in schools, colleges and universities in Nigeria include the following:

1. Difficulty of examination and desire to pass at all cost

2. Unpreparedness of students due to poor teaching and learning

3. Lack of adequate teaching - learning facilities and infrastructure

4. Poor learning .habits of students

5. students wishing to conform with other students' style and not wanting the perceived lazy students to outshine them

6. Logistic problems in printing and handling of examination materials

7. Conduct of examinations in an improvised hall, where there is inadequate sitting materials and bad lighting conditions.

8. Selling of question papers to make money by individuals

9. Poor and ineffective supervision of examinations

10. Desire to satisfy parents

11. Schools' poor attitudes toward examination conduct

12. Moral decadence in the society

13. Quest for certificate/societal education emphasizing knowledge

14. Lack of commitment on the part of the teachers.

15. Inability of the Government to implement the various examination malpractices laws due to lack of political will.

These causes often lead to bribing of examination officials, and teachers and those seeking for illicit help before and mostly during examinations.

Olaitan (2010) opined that the way teaching and learning process in Science, Vocational and Technical Education are carried out and examined in Nigerian schools and colleges may not favourably provide opportunities for effective learning and acquisition of job skill required in various occupational areas. He observed that most of the student copied from text books. Alternate to practical questions are marred with examination malpractice while the general mode of assessment of vocational education programmes are mostly through paper and pencil methods which predisposes examinees to examination irregularities, malpractice and other vices.

\section{Proposed Modes of Assessing Learning Outcomes in Sciences, Vocational and Technical Education to Prevent Examination Malpractice}

The success of any science, vocational and technical education in making substantial contribution to the economy and technological development of a nation depends on the effective teaching and learning of the psychomotor and effective domains of learning as against the common emphasis on cognitive domain and rote learning alone which encourages examination malpractice. The consequences of rote learning is that the students are to memorize theories and principles with little or no practicals in relation to how the theories could be applied to solve challenging problems in specific work or 
job areas. The teaching and learning process in most cases are abstract and theory oriented. The assessment processes are often very subjective, where multiple choice questions are asked, students might have not covered the syllabus or rather not well taught.

It is a known fact that the assessment of learning outcomes in sciences vocational and technical education requires a more pragmatic approach and performance based approach than the paper and pencil mode of evaluating students performance, For example, the National Board for Technical Education (1991) recommended the development and usage of modules for effective teaching of skills. In this case, performance based tests are needed for the modules which contain the tasks to be taught to students in schools and colleges.

A module represents the learning materials interactively making assessment to be performance or practice based. In which case, a step in the module should be fully satisfied before moving to the next step. Evaluation of the modules (if actually carried out to the letters) will be real and exact due to "on the spot assessment". Assessment of learning outcomes through appropriate strategy should manifest effectively through job placement or assessment of ability to solve a particular problem or trouble shoot.

\section{Performance Based Assessment - An Approach to Minimize Examination Malpractice in Science and Vocational Education}

Vocational and Technical Education emphasizes learning by doing which is accomplished through measurable performance of learning activities. Olaitan (1998) and Fatunsin recommended the; following three (3) major approaches to assessing performance of skill learning outcomes in vocational education programmes. The approaches are:

i. Administration of performance Based Tests

ii. Observation with rating scales and checklists on tasks and

iii. Pragmatic continuous assessment of students' accomplishment, competency acquired in specific tasks.

A Performance Based Test According to Green (1975) and Fatunsin (1996) is the test designed specifically to measure directly the actual job performance of students in the area being taught.

\section{Components of Performance Based Tests (PBT)}

The following are the major component of Performance Based Test.

1. Developing activity packaged from the content of the programme, the activities are organized in order of performance. This allows for easy assessment.

2. Developing performance objectives to guide the teachers in developing the test items.

3. Selecting appropriate psychomotor domain/criteria or specification for the activities

4. Constructing performance based multiple choice tests using the three (3) parameters earlier stated. The Multiple choice test should be on continuous assessment modules, to cover the whole content of the curriculum

5. Every skill development modules are to be assesses through a chain of Tasks to be accomplished using checklisting and Rating scale.

The major advantages of this approach is that it is appropriate for a large number of students on different programme areas.

An example of performance Based Assessment Approach, on the course Simple Engine in a practical agricultural science or technical education. (Automobile) include the following steps:

\section{Major Steps Required to make Performance Based Tests to work}

1. Students are provided with a simple 2 stroke engine to dismantle and make to work.

2. The students are provided with all accessories and tools necessarily for the repairs and fault detection.

3. Students are given the manual or instruction booklet to follow in the problem-solving episode.

4. Students can interact with others because the problems on individual machines are likely to differ but the main purpose is to make the machine work.

5. Students are to dismantle the engine and make it to work.

6. Students performance are measured on the following criteria among others: (a) the time spent to make the engine to start on the first, second and third time (b) Level of skill here, students can grade themselves and 
examination malpractice are reduced to the minimum.

Similarly in a Wood Work Class, where students are made to construct a standard chair.

a. modern chair would be provided as sample for the students.

b. Student can ask questions from one another through interaction.

c. They can make references to manuals or instruction book. The focus is to construct a standard chair. Grades are therefore a warder based on the following,

a. The pre-set tasks expected in a check list

b. Hours spend to complete the construction. Here examination malpractices are bound to be minimized, while the level of accomplishment, competency and performance on the job are assessed.

\section{Observation with Rating Scale and Checklist on Skill/Tasks,}

Using a Rating scale or checklist, the items on each task can be accessed based on the level of performance expected on a five point rating scales. A careful use of this rating scales is capable of yielding information of a students level of performance. The use of rating scales in assessing students' performance has an advantage over the use of checklisting because the check list only shows whether trait or bahavlour is there or not. But rating scale goes further to show the level of performance or possession of specific trail. The use of checklist, however, can accommodate more students during an assessment period arid its not time consuming. It can also be effective in assessing students during their earlier formative years in the skills learning process.

\section{Monitored Continuous Assessment Approach}

Continuous Assessment makes use of the steps adopted in the earlier approaches but tries to assess the effective performance of students in the process on learning rather than the product. If well administered continuous assessment gives both teachers and students the knowledge of level of performance on each competency or task before the final product evolves.

This continuous assessment should be strictly monitored to avoid sentiments. Proper records should be well processed and kept. The continuous assessment should be based the following parameters.

- Skills acquired through accomplishment of predetermine tasks through checklisting.

- Knowledge acquired through classroom interaction

- Assignments/projects carried out

- Teachers/students interaction hours

The objectives of the three (3) approaches could be better achieved through the following processes:

1. Determining and state the goal of each programme

2. Defining the objectives of each programme.

3. Specifying the performance criteria

4. Developing appropriate assessment instruments to use

5. Assessing the instructions, teachers, facilities, equipment and other services to accomplish the set objectives.

6. Determining level of students' performances

7. Giving feedback on students' level of performance and keep records.

\section{Conclusion}

It has been established that the assessment of learning outcomes in science, vocational and technical education requires a more pragmatic approach through performance based teaching and evaluation than the paper and pencil mode of evaluation that encourages examination malpractice.

\section{Recommendations}

It is recommended that:

1. Performance-based evaluation process through rating scale, check listing and monitored continuous assessment should be adopted as antidotes to prevent and control examination malpractice and its vices in science, vocational and technical education subject areas in schools and colleges in Nigeria. 
2. Continuous assessment in science vocational and technical education should be based on projects completed, skills acquired, special assignments completed, attendance on the farm and in workshops and specified affective accomplishment.

3. All continuous assessment performance should be documented in regular basis and used effectively to determine performance.

4. Accurate record keeping of students performance should be encouraged by all Heads of schools and colleges so as to keep students performance record intact.

5. Seminars, training and retraining programmes should be organised for all science, vocational and technical education teachers on the use of table of specification and performance based testes.

6. The use of computer based examination and tests should be intensified in all schools and colleges in Nigeria.

\section{References}

Amadi M.N (2011) Current Issues and Trends in Nigerian Higher Education. Lagos: Vitaman Educational Books.

Fagbemiro E.O (1998) Examination Malpractice in Nigerian Educational Institutions: Is there any hope? in Adegboye A. Olutoye O., and Adetuberu J.O (Eds) Issues on Examinational Malpractices in Nigeria. A Book of Readings. Ikere-Ekiti, Ondo State? College of Education.

Fajemidagba M.O., Solomon M.F, Olawoye F.A (2011) University Undergraduates Views on the Use of Laboratory Based Strategy in the Teaching of Mathematics. Journal of Research in Education. I (I), 104-119.

Famiwole R.O (1998) Perspective of Students Involvement in Examination Malpractice in Adegboye A., Olutoye O., Adetuberu J.O (Eds) Issues in Examination Malpractices in Nigeria. A Book of Readings. Ikere-Ekiti, Ondo State College of Education.

Fatusin, L.O. (1996) Performance Based Standard Test for Assessing Students in Agriculture in Secondary Schools in Ondo State. An Unpublished Ph.D Thesis. University of Nigeria Nsukka.

National Policy on Education (2004) Abuja: Federal Ministry of Education.

Green J.A (1975) Teacher Made Tests. New York: Haper and Row Publisher.

Lagos State Government (1992) Issues of Examination Malpractice in the SSCE. A Paper Presented at the Lagos State Contribution to the Public Debate in Examination Malpractices.

National Board for Technical Education (1991) Managing Resources for Effective Lower and Middle Lever Man Power Training in Agriculture. Proceedings of a National Seminar Organized by National Board for Technical Education for Agriculture Colleges in Nigeria Kaduna.

Olaitan S.O, (1998) Vocational and Technical Administration in Nigeria. Issues and Analysis. Onitsha, Noble Graphic Press.

Olaitan, S.O. (2010). The Potential of Vocational and Technical Education for Empowering Youths and Vulnerable Adults with Work-skill for Poverty Reduction in Nigeria. Journal of Vocational Education 1, (7), 1-8.

Oluyeba, M.F. and Daramola (1992). Incidence and Detection of Examination Malpractices in Nigeria: Public Examination. A Paper of Benin Benalty August 1992.

Oluyeba, M.F. (1998). Examination Malpractices a Recurring Decimal in Education Assessment in Nigeria. In Adegboye A, Olutoye O, Adetuberu, J.O. (Eds) Issues in Examination Malpractices in Nigeria. A Book of Readings. Ikere-Ekiti: Ondo State College of Education. 
